\title{
Progestin-Binding Protein in Human Benign Prostatic Hypertrophy
}

\author{
TAK AOMI KODAMA, MASAKo ITO, RYOKo SATO \\ HARUO ITO AND JUN SHIMAZAKI \\ Department of Urology, School of Medicine, \\ Chiba University, Chiba 280
}

\begin{abstract}
Cytosols from human benign prostatic hypertrophy contained progestin-binding components which bound to R 5020, ORG 2058 and progesterone in a high affinity fashion. Most of the protein bound to $\mathrm{R} 5020$ was recovered in the precipitate with $0-30 \%$ saturation of ammonium sulfate. The $R$ 5020-binding protein showed sedimentation coefficients of $3.6 \mathrm{~S}$ and $8.4 \mathrm{~S}$, and was eluted in the void volume of a Sephadex G-200 column. This protein was clearly distinguished from the dihydrotestosterone-binding protein by its precipitability by ammonium sulfate, heat stability and susceptibility to delipidization. R 5020 and ORG 2058 binding were markedly inhibited by the addition of $R 1881$, therefore, most of the binding to progestin in cytosols from the benign prostatic hypertrophy seems to be also the sites for $\mathrm{R} 1881$. Although nuclear extract by $0.4 \mathrm{M} \mathrm{KCl}$ showed $\mathrm{R} 1881$ binding, the extract did not contain the $\mathrm{R}$ 5020-binding protein, and thisi suggested that the progestin-binding protein observed in the cytosols does not seem to be the steroid receptor.
\end{abstract}

It was observed recently that the human prostate contained many kinds of androphilic protein which bound to androgen in a high affinity fashion. These proteins included the testosterone-binding globulin from the blood plasma, the androgen receptor which has similar properties to those observed in the rodent prostate, and other high affinity proteins to androgens (Menon et al., 1977; Shain and Boesel, 1978). R 1881 (methyltrienolone, $17 \beta$-hydroxy-17 $\alpha$-methylestra-4, 9, 11-trien-3-one) have been introduced for estimation of the androgen receptor in the human prostate because of its specificity in binding to the androgen receptor (Asselin et al., 1976, Dubé et al., 1976). However, it was shown later that the $\mathrm{R}$ 1881-binding protein was bound also to progestin with higher affinity than to

Recieved January 6, 1981. dihydrotestosterone ( $5 \alpha$-androstan-17 $\beta$-o1-3one) (Menon et al., 1978). Therefore, the $\mathrm{R}$ 1881-binding protein in the human prostate is more likely, different from that observed in the rodent prostate, to be the progestin-binding protein and not the androgen receptor. The present work was undertaken to clarify the nature of progestinbinding protein in tissues of the human benign prostastic hypertrophy.

\section{Materials and Methods}

\section{Steroids}

Labeled and unlabeled R 5020 (Promegeston, [17 $\alpha-$ methyl-3 ${ }^{3}$ ] 17,21-dimethy1-19-nor-pregna-4,9-dien3,20-dione, specific activity $87 \mathrm{Ci} / \mathrm{mmol}$ ), and labeled and unlabeled R 1881 (Methyltrienolone, [17 $\alpha$-methyl$\left.{ }_{3}^{3} \mathrm{H}\right]$ 17 $\beta$-hydroxy-17 $\alpha$-methyl-estra-4, 9, 11-trien-3one, specific activity $87 \mathrm{Ci} / \mathrm{mmol}$ ) were purchased from New England Nuclear (Boston, Mass. U.S.A.). Labeled and Unlabeled ORG $2058([6,7-3 \mathrm{H}] 16 \alpha-$ 
ethyl-21-hydroxy-19-nor-pregn-4-en-3, 20-dione, specific activity $58 \mathrm{Ci} / \mathrm{mmol}),{ }^{3} \mathrm{H}$-dihydrotestosterone $\left(\left[1,2,4,5,6,7-{ }^{3} \mathrm{H}\right] 5 \alpha\right.$-dihydrotestosterone, specific activity $101 \mathrm{Cilmmol})$ and ${ }^{3} \mathrm{H}$-progesterone $([1,2,6$, 7-3 $\mathrm{H}$ ] 4-pregnen-3, 20-dione, specific activity 101 $\mathrm{Ci} / \mathrm{mmol}$ ) were obtained from The Radiochemical Centre (Amersham, U.K.).

\section{Materials}

Tissues of the human benign prostatic hypertrophy were obtained surgically from patients admitted to Chiba University Hospital. Immediately after removal, tissues were cut into small pieces, placed on ice and carried to the laboratory. Some tissues were quickly frozen and kept at $-80^{\circ} \mathrm{C}$ until processing. All tissues were examined histologically to confirm their pathological state.

\section{Tissue preparation}

Tissues were homogenized in 5 volumes of $0.01 \mathrm{M}$ Tris- $\mathrm{HCl}$ buffer ( $\mathrm{pH}$ 7.4) containing $1 \mathrm{mM}$ EDTA, $1 \mathrm{mM} \beta$-mercaptoethanol and $10 \%(\mathrm{w} / \mathrm{v})$ glycerol (TEMG buffer) using a glass homogenizer and filtered through nylon cloth. Cytosols were obtained after centrifuging the homogenates successively at $700 \times g$ for $10 \mathrm{~min}, 8,000 \times g$ for $15 \mathrm{~min}$ and $105,000 \times g$ for $60 \mathrm{~min}$. To obtain purified nuclei, fresh tissues were homogenized in 10 volumes of the medium which consisted of $0.05 \mathrm{M}$ Tris $-\mathrm{HCl}, 0.25 \mathrm{M}$ sucrose, $3 \mathrm{mM} \mathrm{MgCl}_{2}$ and $0.025 \mathrm{M} \mathrm{KCl}$ ( $\mathrm{pH} 7.4$, TSMK buffer) and spun at $700 \times g$ for $10 \mathrm{~min}$. The crude nuclear fraction thus precipitated was washed with TSMK buffer, and purified according to the method of Blobel and Potter (1966).

\section{Preparation of delipidized cytosol}

Some cytosols were delipidized and precipitated by adding 9 volumes of chilled acetone according to the method described by Ichii (1975). The acetonedried cytosol was suspended in TEMG buffer, homogenized briefly, then spun, and the resultant supernatant was used for binding studies.

\section{Fractionation by ammonium sulfate}

Cytosols prepared in TEM buffer (glycerol-omitted TEMG buffer) were fractionated by the addition of ammonium sulfate at $4^{\circ} \mathrm{C}$. The resultant precipitate was dissolved in the same buffer and dialysed against the same buffer for $1 \mathrm{~h}$ under vigorous stirring.

\section{Sephadex G-200 chromatography}

The cytosol fraction precipitated by $0-30 \%$ saturation of ammonium sulfate was incubated in TEMG buffer with $2.5 \mathrm{nM}$ of $3 \mathrm{H}-\mathrm{R} 5020$ in the presence or absence of $2.5 \mu \mathrm{M}$ radioinert $\mathrm{R} 5020$ at $15^{\circ} \mathrm{C}$ for $3 \mathrm{~h}$. After incubation, 0.05\% dextran (T 70, Pharmacia,
Uppsala, Sweden)-coated $0.5 \%$ charcoal (Norit A Wako Pure Chemicals, Osaka, Japan) was added, centrifuged, and the resultant supernatant was chromatographed on a column of Sephadex G-200 (1× $90 \mathrm{~cm}$, Pharmacia, Uppsala, Sweden). The column was eluted with TEMG buffer.

\section{Sucrose density gradient centrifugation}

Cytosol was incubated with $2.5 \mathrm{nM}$ of $3 \mathrm{H}-\mathrm{R} 5020$ at $15^{\circ} \mathrm{C}$ for $3 \mathrm{~h}$. The dextran-coated charcoal was added, centrifuged, and $0.3 \mathrm{ml}$ of the resultant supernatant was applied on the top of $5-20 \%$ sucrose gradient in TEMG buffer $(5 \mathrm{ml})$. Centrifugation was performed with a RPS65T rotor in an Hitachi Ultracentrifuge (80 P, Hitachi Co., Tokyo, Japan) at $164,000 \times g$ for $16 \mathrm{~h}$. After centrifugation, the gradient was fractionated into $0.2 \mathrm{ml}$ fractions using a density gradient fractionator (Isco, Model 640, Lincoln, Nebraska, U.S.A.). Radioactivity in the fractions was counted after the addition of toluene containing $0.4 \%$ PPO and $0.01 \%$ POPOP. Bovine serum albumin and human immunoglobulin $\mathrm{G}(\mathrm{IgG})$ were used as references for calculation of the sedimentation coefficient.

\section{Preparation of nuclear extract}

Purified nuclei was suspended in TEMG buffer containing $0.4 \mathrm{M} \mathrm{KCl}$ and were stirred at $4^{\circ} \mathrm{C}$ for $30 \mathrm{~min}$. After centrifugation, the precipitate was reextracted in the same manner. The combined supernatant was referred to as the nuclear extract.

\section{Saturation analysis of the binding}

Samples to be analyzed were incubated in $0.5 \mathrm{ml}$ of TEMG buffer containing various concentrations $(0.25-5 \mathrm{nM})$ of ${ }^{3} \mathrm{H}-\mathrm{R} 5020$ at $15^{\circ} \mathrm{C}$ for $3 \mathrm{~h}$. Incubation of the nuclear extract was performed at $4^{\circ} \mathrm{C}$ for $18 \mathrm{~h}$. When bindings to other ${ }^{3} \mathrm{H}$-ligands were examined, incubation conditions were changed: $4^{\circ} \mathrm{C}$ $5 \mathrm{~h}$ in ORG $2058,4^{\circ} \mathrm{C} 3 \mathrm{~h}$ in progesterone, $4^{\circ} \mathrm{C}$ $2 \mathrm{~h}$ in dihydrotesterone and $4^{\circ} \mathrm{C} 6 \mathrm{~h}$ in $\mathrm{R} 1881$, respectively. In the case of ${ }^{3} \mathrm{H}$-progesterone, 100 fold molar excess of radioinert cortisol was added to the incubation medium (Kontula, 1975). ${ }^{3} \mathrm{H}-$ Steroid was dissolved in $10 \mu 1$ of ethanol and added to the incubation medium. When the effect of the addition of various steroids was examined, another $5-10 \mu 1$ of ethanol solution of additives was added to the incubation medium.

After incubation, dextran-coated charcoal was added, centrifuged, and radioactivity in an aliquot of the supernatant was counted in $15 \mathrm{ml}$ of toluene containing $0.4 \%$ PPO and $0.01 \%$ POPOP. In parallel incubations, 1000 -fold molar excess of unlabeled ligand was added to the incubation tube. Nonspecific binding which was not displaced under these conditions was subtracted in all instances. Approximately $40-60 \%$ of the binding to ${ }^{3} \mathrm{H}-\mathrm{R} 5020$ was 


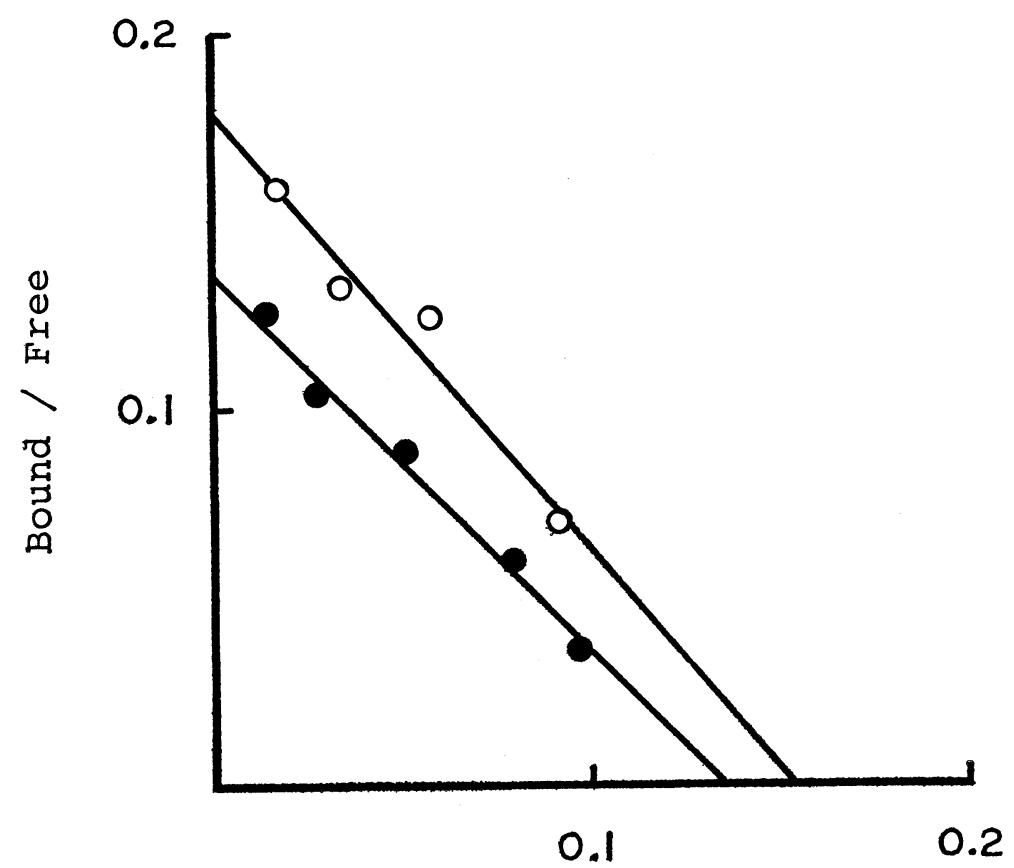

Fig. 1. Binding to $\mathrm{R} 5020$ of cytosol and of fraction precipitated with $0-30 \%$ saturation of ammonium sulfate. The cytosol and the ammonium sulfate fraction were incubated with various concentrations $(0.25-5 \mathrm{nM})$ of ${ }^{3} \mathrm{H}-\mathrm{R}$ 5020 at $15^{\circ} \mathrm{C}$ for $3 \mathrm{~h}(4.5$ $\mathrm{mg}$ as protein of cytosol/ tube; open circle, $2.7 \mathrm{mg}$ as protein of $0-30 \%$ fraction/tube; closed circle). Kd (dissociation constant) and maximum binding sites calculated from Fig. were $1.7 \times 10^{-9} \mathrm{M}$ and 34 fmol/mg protein (cytosol), and $2.0 \times 10^{-9} \mathrm{M}$ and 50 $\mathrm{fmol} / \mathrm{mg}$ protein $(0-30 \%$ fraction), respectively.

\section{Bound ( $p$ moles )}

nonspecific binding. Binding capacity and affinity were analyzed by the method of Scatchard (1949).

\section{Protein determination}

Protein was measured either by the ultraviolet absorption at $280 \mathrm{~mm}$ (Tombs et al., 1959) or by the biuret method (Gornall et al., 1949) with bovine serum albumin as the calibration standard.

\section{Results}

Binding to ${ }^{3} \mathrm{H}-\mathrm{R}$ 5020, ${ }^{3} \mathrm{H}-\mathrm{ORG} 2058$ and ${ }^{3} H$-progesterone of cytosols from the human benign prostatic hypertrophy

Saturation analysis of the binding to ${ }^{3} \mathrm{H}-\mathrm{R} 5020$ of cytosols revealed a high affinity binding and the number of binding sites per $\mathrm{mg}$ protein of the cytosol was limited (Fig. 1). The protein which explains the binding to ${ }^{3} \mathrm{H}-\mathrm{R} 5020$ in the cytosols was mostly in the fraction precipi- tated with $0-30 \%$ saturation of ammonium sulfate, and treatment of the cytosol with ammonium sulfate did not modify the $\mathrm{Kd}$ (dissociation constant) of the binding. In the fraction precipitated by more concentrated ammonium sulfate, only a small amount of ${ }^{3} \mathrm{H}-\mathrm{R} 5020$ binding was observed (data not shown).

The rate of the binding of cytosols to ${ }^{3} \mathrm{H}-\mathrm{R} 5020$ and ${ }^{3} \mathrm{H}-\mathrm{R} 1881$ was decreased extensively after heating the cytosol at $50^{\circ} \mathrm{C}$ for $30 \mathrm{~min}$, while the effect of the heating on the binding to ${ }^{3} \mathrm{H}$-dihydrotestosterone was relatively moderate (Table 1 ). Delipidization by chilled acetone resulted in the complete elimination of the binding to ${ }^{3} \mathrm{H}$ R 5020 and ${ }^{3} \mathrm{H}-\mathrm{R} 1881$, but the binding to ${ }^{3} \mathrm{H}$-dihydrotestosterone was still observed.

A high affinity binding to other progestins such as ${ }^{3} \mathrm{H}$-ORG 2058 and ${ }^{3} \mathrm{H}$-progesterone (Fig. 2) was also observed in the 
Table 1. Effect of heating and delipidization on the binding of cytosol to dihydrotestosterone, R 1881 and R 5020 .

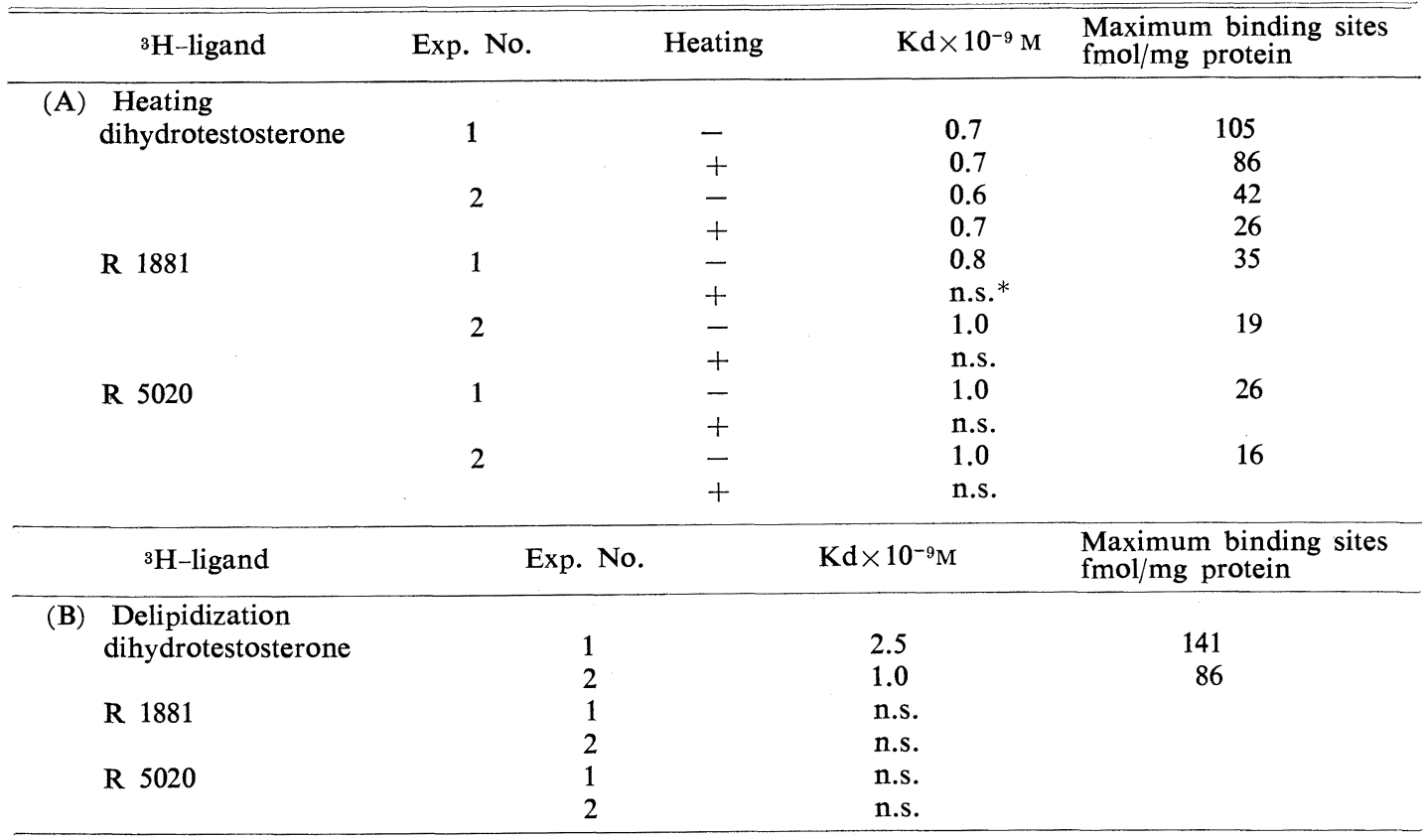

*: Only nonspecific binding was observed.

(A) The cytosol $(4.7 \mathrm{mg}$ and $3.9 \mathrm{mg}$ as protein/tube in Exp. 1 and 2, respectively) was heated at $50^{\circ} \mathrm{C}$ for $30 \mathrm{~min}$, then incubated with the various concentrations $(0.25-5 \mathrm{nM})$ of ${ }^{3} \mathrm{H}$-ligand indicated in the table, and results were compared with those of the unheated controls.

(B) The cytosol $(4.2 \mathrm{mg}$ and $2.9 \mathrm{mg}$ as protein/tube in Exp. 1 and 2, respectively) was delipidized by chilled acetone and incubated with the various concentrations $(0.25-5 \mathrm{nM})$ of ${ }^{3} \mathrm{H}$-ligand indicated in the table.

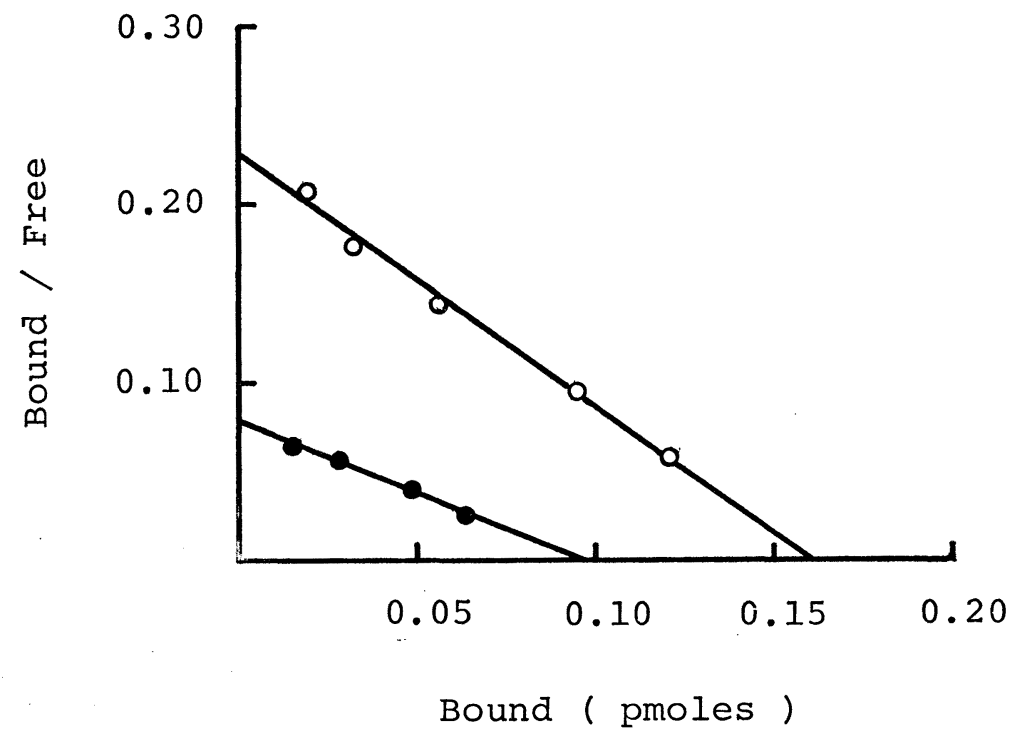

Fig. 2. Binding of cytosol to ORG 2058 and progesterone. Cytosol $(3.3 \mathrm{mg}$ protein/tube) was incubated with various concentrations $(0.25-5 \mathrm{nM})$ of ${ }^{3} \mathrm{H}$ ORG 2058 (open circle, at $4^{\circ} \mathrm{C}$ for $5 \mathrm{~h}$ ) or ${ }^{3} \mathrm{H}$-progesterone (closed circle, at $4^{\circ} \mathrm{C}$ for $3 \mathrm{~h}$ ). In the incubations with ${ }^{3} \mathrm{H}$-progesterone, a 100-fold molar excess of cortisol was supplemented. $\mathrm{Kd}$ and maximum binding sites calculated from Fig. were $1.4 \times 10^{-9} \mathrm{M}$ and 48 $\mathrm{fmol} / \mathrm{mg}$ protein (ORG 2058 ), and $2.5 \times 10^{-9} \mathrm{M}$ and $29 \mathrm{fmol} / \mathrm{mg}$ protein (progesterone), respectively. 


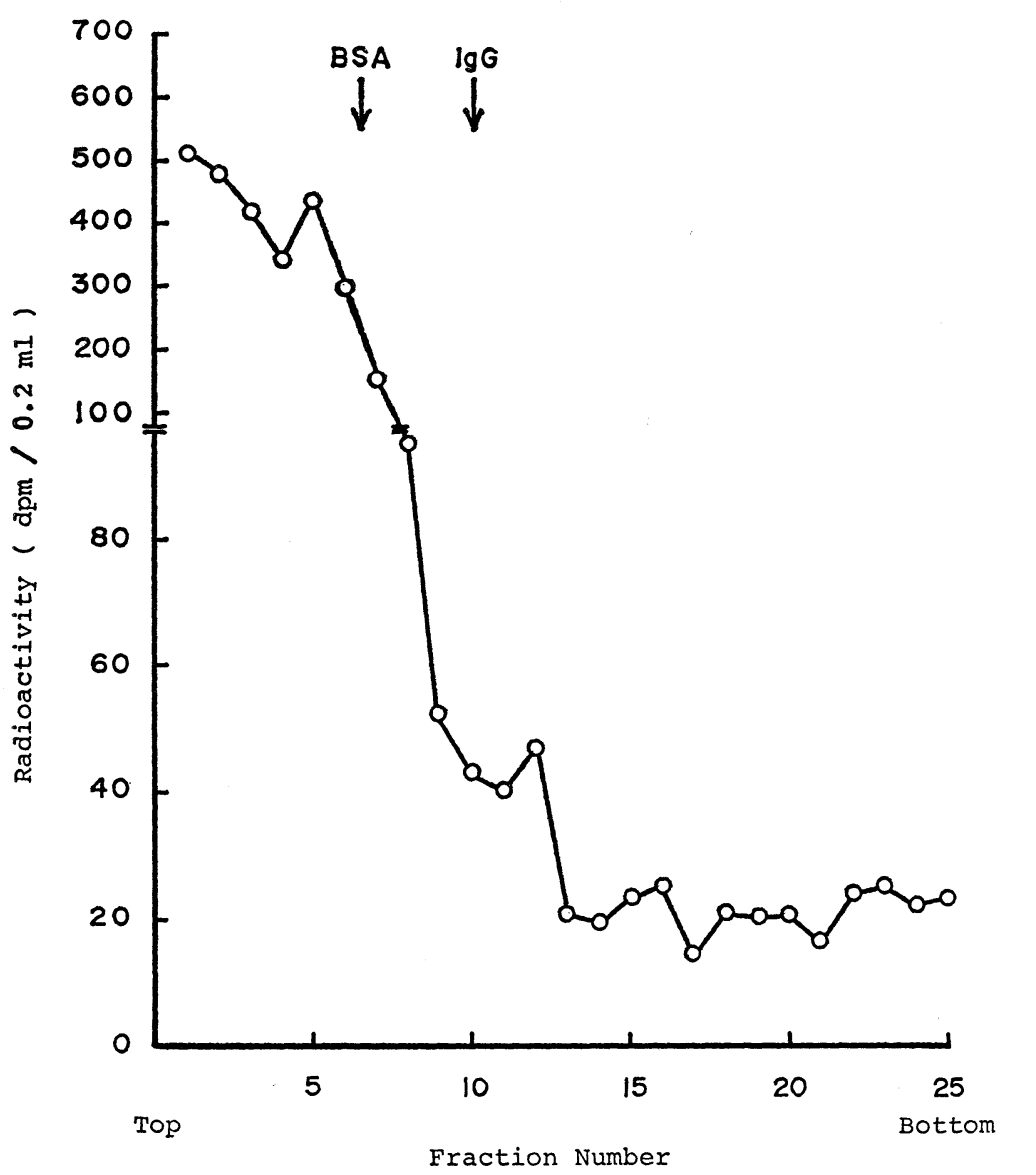

Fig. 3. Sucrose density gradient centrifugation of cytosol after incubation with ${ }^{3} \mathrm{H}-\mathrm{R} 5020$. An aliquot of the cytosol $(0.3$ $\mathrm{m} l, 1.4 \mathrm{mg}$ as protein) prelabeled with ${ }^{3} \mathrm{H}-\mathrm{R} 5020$ was applied on the top of a $5-20 \%$ sucrose gradient containing $10 \%(\mathrm{w} /$ v) glycerol and was centrifuged at $164,00^{\circ} 0 \times \mathrm{g}$ for $16 \mathrm{~h}$. Each $0.2 \mathrm{ml}$ fraction was collected and the radioactivity in each fraction was counted. Arrows indicate the location of markers (B.S.A.; bovine serum albumin $[4.6 \mathrm{~S}]$, IgG [7S]).

cytosols. Therefore, cytosols from human benign prostatic hypertrophy apparently contain progestin-binding protein.

Cytosol prelabeled with ${ }^{3} \mathrm{H}-\mathrm{R} 5020$ was fractionated by sucrose density gradient centrifugation (Fig. 3). A large radioactive peak was observed at $3.6 \mathrm{~S}$ and an additional small one was noticed shortly after IgG (8.4S). By adding the 100-fold molar excess of radioinert $\mathrm{R} 5020$ to the incubation, the 8.4S peak was eliminated and the $3.6 \mathrm{~S}$ peak was diminished (data not shown).

The cytosol fraction precipitated with $0-30 \%$ saturation of ammonium sulfate was incubated with ${ }^{3} \mathrm{H}-\mathrm{R} 5020$ in the presence or absence of 1000-fold molar excess of radioinert $\mathrm{R}$ 5020. After the removal of free steroid by dextran-coated charcoal, an aliquot of the incubated fraction was chromatographed on a Sephadex G-200 column (Fig. 4). The radioactive fraction was eluted in the void volume, and the addition of radioinert $\mathrm{R} 5020$ reduced the radioactivity in the void volume.

Inhibition of ${ }^{3} \mathrm{H}-\mathrm{R} 5020$ and ${ }^{3} \mathrm{H}-\mathrm{ORG} 2058$ binding by other steroids

Cytosol from the human benign prostatic hypertrophy was incubated with various concentrations of ${ }^{3} \mathrm{H}-\mathrm{R} 5020$ in the presence or absence of an excess amount of either dihydrotestosterone, $\mathrm{R} 1881$ or progesterone (Fig. 5). These additives inhibited the ${ }^{3} \mathrm{H}$ R 5020 binding competitively. To evaluate 

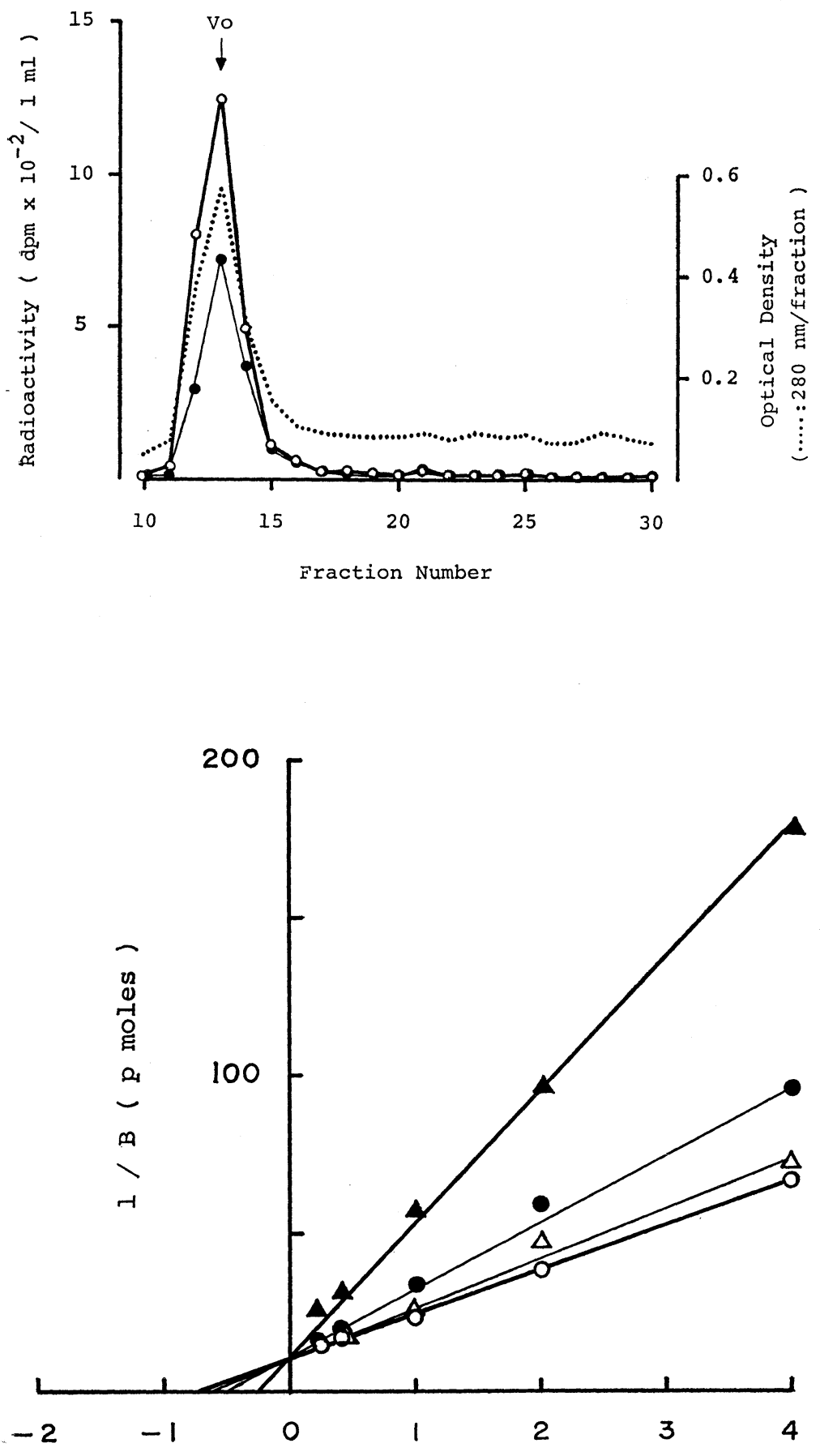

$1 / \mathrm{nM}$
Fig. 4. Sephadex G-200 chromatography of the 0 $30 \%$ fraction prelabeled with ${ }^{3} \mathrm{H}-\mathrm{R}$ 5020. The cytosol was precipitated with $0-30 \%$ saturation of ammonium sulfate, dissolved in TEMG buffer and incubated with $2.5 \mathrm{nM}$ of ${ }^{3} \mathrm{H}-\mathrm{R} 5020$ in the presence (closed circle) or absence (open circle) of $2.5 \mu \mathrm{M}$ of radioinert $\mathrm{R} 5020$. An aliquot of the fraction $(1.8 \mathrm{ml}, 5.4 \mathrm{mg}$ as protein) was applied to a Sephadex G-200 column $(1 \times 90$ $\mathrm{cm})$ and the column was eluted with TEMG buffer at fiow rate of $5.1 \mathrm{ml} / \mathrm{h}$. Each $1.6 \mathrm{ml}$ of the elute was collected. Vo: void volume.

Fig. 5. Inhibition of the $R$ 5020 binding of cytosol by dihydrotestosterone, $\mathbf{R}$ 1881 and progesterone. The cytosol $(2.2 \mathrm{mg}$ as protein/tube) was incubated with various concentrations $(0.25-5 \mathrm{nM})$ of ${ }^{3} \mathrm{H}-$ $\mathrm{R} 5020$ in the presence of $100 \mathrm{nM}$ of dihydrotestosterone (open triangle), 10 $\mathrm{nM}$ of R 1881 (closed triangle) or $10 \mathrm{nM}$ of progesterone (closed circle) at $15^{\circ} \mathrm{C}$ for $3 \mathrm{~h}$. $\mathrm{Kd}$ and maximum binding sites of the cytosol incubated in the absence of inhibitor (open circle) were $1.0 \times$ $10^{-9} \mathrm{M}$ and $36 \mathrm{fmol} / \mathrm{mg}$ protein, respectively. 


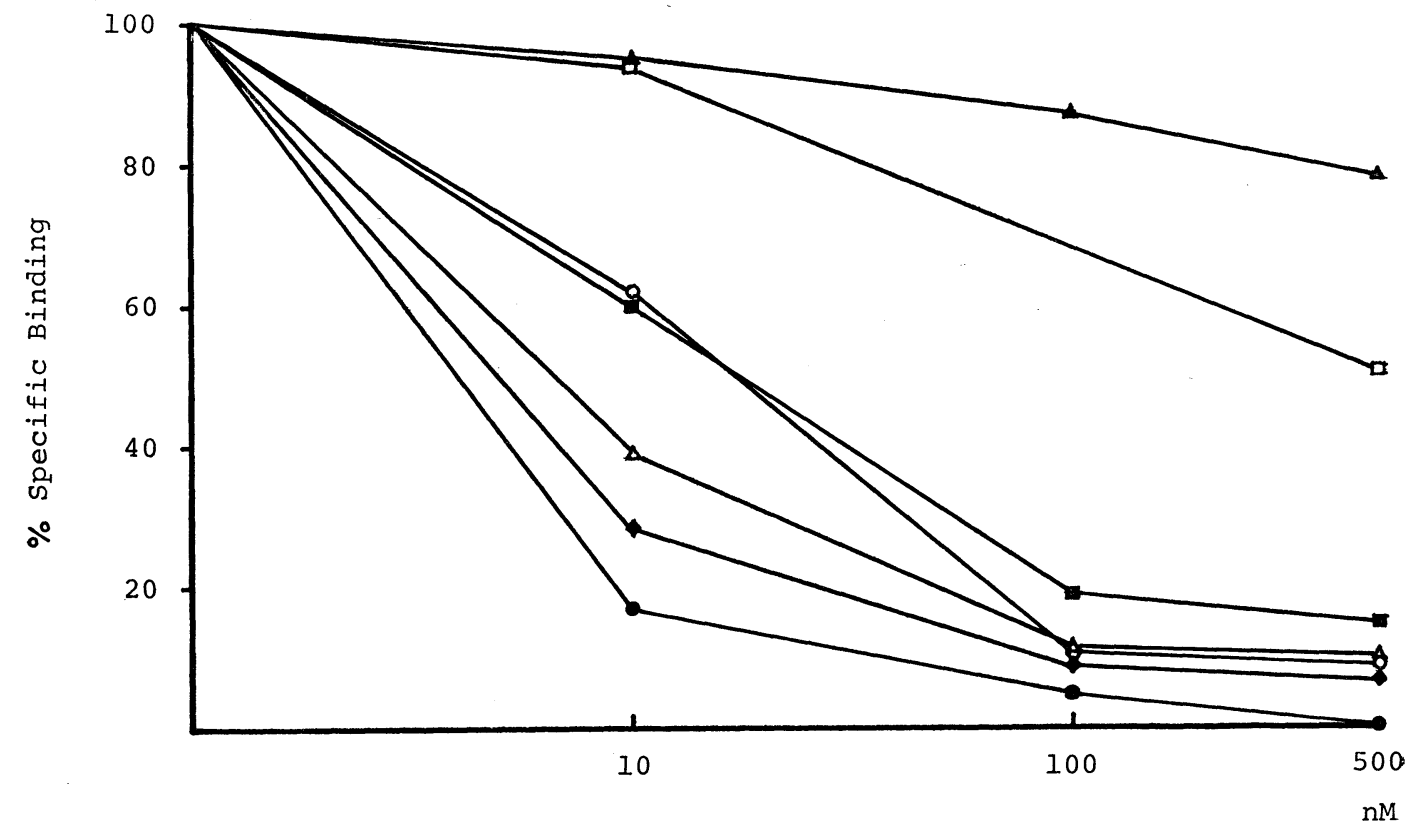

Excess Cold Competitor

Fig. 6. Inhibition of the R 5020 binding of cytosol by various steroids. The cytosol (4.3 mg as protein/ tube) was incubated with $1 \mathrm{nM}$ of $3 \mathrm{H}-\mathrm{R} 5020$ in the presence of $10-500 \mathrm{nM}$ of radioinert competitors at $15^{\circ} \mathrm{C}$ for $3 \mathrm{~h}$, and the binding was compared to that in the absence of competitors (taken as 100\%). R 5020 (closed circle), ORG 2058 (closed diamond), R 1881 (open triangle), progesterone (open circle), cyproterone acetate (closed square), dihydrotestosterone (open square), estradiol-17 $\beta$ (closed triangle).

the inhibitory effect of various steroids quantitatively, the cytosol was incubated with $1 \mathrm{nM}$ of ${ }^{3} \mathrm{H}-\mathrm{R} 5020$ supplemented with various concentrations $(10-500 \mathrm{~nm})$ of the unlabeled competitors (Fig. 6). Progestins such as ORG 2058, progesterone and cyproterone acetate, and also R 1881 showed strong inhibitions, while dihydrotestosterone and estradiol-17 $\beta$ were rather weak inhibitors. Similar inhibition by these steroids was observed when the ${ }^{3} \mathrm{H}-\mathrm{ORG} 2058$ binding of the cytosol was examined (Fig. 7). It may therefore be concluded that cytosols of the human benign prostatic hypertrophy contain progestin-binding protein which binds also to $\mathrm{R} 1881$ in a high affinity fashion.
Binding of nuclear extract to ${ }^{3} H-R 5020$

The nuclear extract from tissues of the human benign prostatic hypertrophy was incubated in the presence of various concentrations of ${ }^{3} \mathrm{H}-\mathrm{R} 5020$ or ${ }^{3} \mathrm{H}-\mathrm{R} 1881$. A high affinity binding was observed with ${ }^{3} \mathrm{H}-\mathrm{R} 1881$, but binding to ${ }^{3} \mathrm{H}-\mathrm{R} 5020$ was almost negligible (Fig. 8). From these observations, the presence of the progestinbinding component in the nuclear extract is thought to be unlikely.

\section{Discussion}

A potent synthetic progestin, R 5020, has been widely used for the determination 


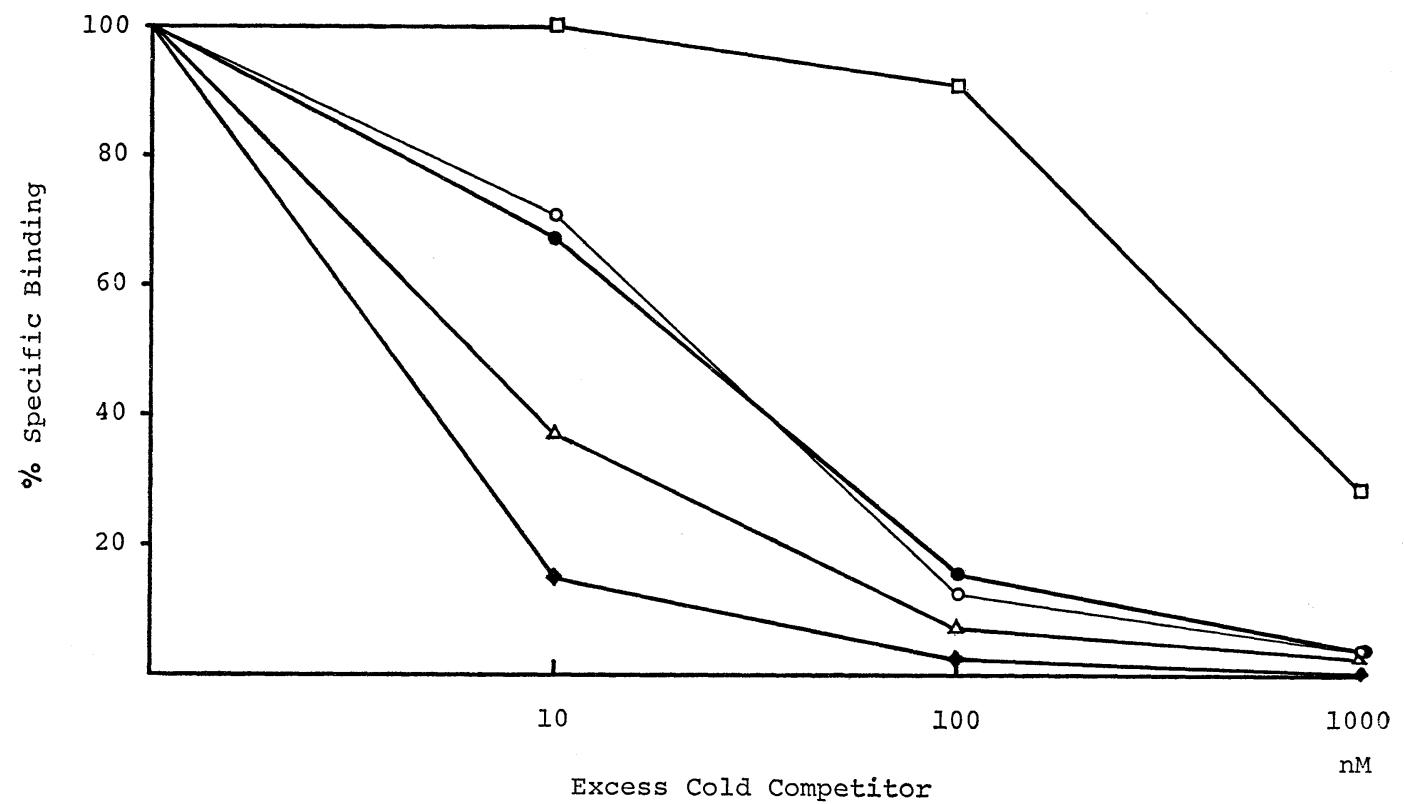

Fig. 7. Inhibition of the ORG 2058 binding of cytosol by various steroids. The cytosol (3.6 mg as protein/tube) was incubated with $1 \mathrm{nM}$ of ${ }^{3} \mathrm{H}-\mathrm{ORG} 2058$ in the presence of $10-1000 \mathrm{nM}$ of radioinert competitors at $4^{\circ} \mathrm{C}$ for $5 \mathrm{~h}$, and the binding was compared to that in the absence of competitors (taken as $100 \%$ ). Symbols are the same as indicated in Fig. 6.

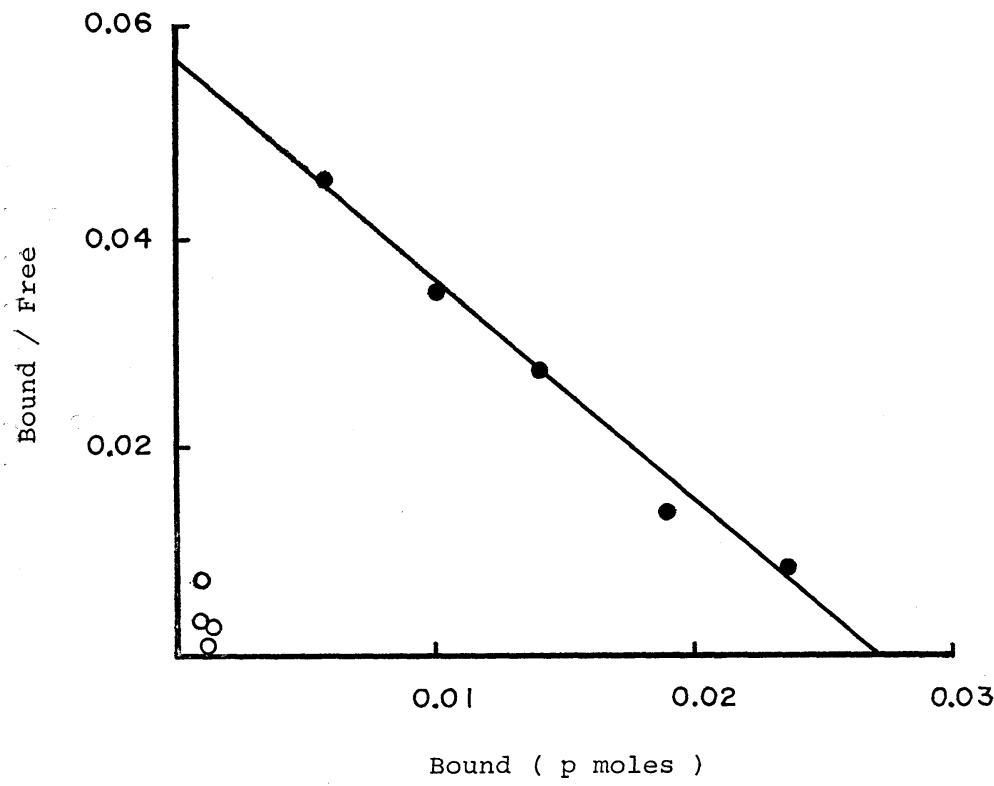

Fig. 8. Binding of nuclear extract to $\mathrm{R} 5020$ and $\mathrm{R}$ 1881. The nuclear extract (1.4 $\mathrm{mg}$ as protein/tube) was incubated with various concentrations $(0.25-5 \mathrm{nM})$ of ${ }^{3} \mathrm{H}-\mathrm{R} 5020$ (open circle) or ${ }^{3} \mathrm{H}-\mathrm{R} 1881$ (closed circle) at $4^{\circ} \mathrm{C}$ for $18 \mathrm{~h}$. $\mathrm{Kd}$ and maximum binding sites on the binding with $\mathrm{R} 1881$ calculated from Fig. were $1.0 \times 10^{-9}$ $\mathrm{M}$ and $19 \mathrm{fmol} / \mathrm{mg}$ protein, respectively. 
of the progestin receptor, because of its high affinity in binding, low rate in dissociation, and also of specificity in binding, negligible binding to plasma corticosteroidbinding globulin (Philibert et al. 1977). Another potent synthetic progestin, ORG 2058, showed almost identical binding properties to those of $\mathrm{R} 5020$ in binding to the progestin receptor (Jänne et al., 1976; Koenders et al., 1979). Therefore, R 5020 and ORG 2058 have been considered progestin binders with high specificity. It was reported by several investigators (Cowan et al., 1977; Shain et al., 1978; Menon et al., 1978) that cytosols from the human benign prostatic hypertrophy contained $R$ 5020-binding protein. Cancerous human prostate also showed a high affinity binding to $\mathrm{R} 5020$ (Ekman et al., 1979). In the present study, a high affinity binding to $\mathrm{R}$ 5020, ORG 2058 and progesterone in cytosols from the human benign prostatic hypertrophy was also observed. These observations might indicate the presence of progestin receptor in the human benign prostatic hypertrophy.

Only a R 5020-binding component which has the sedimentation coefficient of $4 \mathrm{~S}$ was reported by Gustafsson et al. (1978) and Tilley et al. (1980). However, an additional $\mathrm{R}$ 5020-binding protein sedimented at $8.4 \mathrm{~S}$ which was identical to that of the R 1881binding protein was observed in the present experiments (Kodama et al., 1980).

Physicochemical properties of the R 5020binding protein were different from those of the dihydrotestosterone-binding protein; the former was precipitated with $0-30 \%$ saturation of ammonium sulfate, while the latter was in the fraction of $30-50 \%$ saturation. Differences in the heat stability and the susceptibility to delipidization were also observed in the previous and the present experiments (Kodama et al., 1977; Kodama and Shimazaki, 1979). The properties of $\mathrm{R}$ 1881-binding protein in cytosols from the human benign prostatic hyper- trophy were almost identical to those observed in the $\mathrm{R}$ 5020-binding protein (Kodama et al., 1980). The $\mathrm{R} 1881$ - and $\mathrm{R}$ 5020-binding proteins were sedimented between the site of $8 \mathrm{~S}$ and $9 \mathrm{~S}$ on sucrose density gradient centrifugation and these two proteins were eluted in similar fractions on a Sephadex G-200 colum. Furthermore, a reciprocal inhibition on the binding of these ligands was observed. Therefore, it seems plausible that most of the binding sites for R 5020 in cytosols from the benign prostatic hypertrophy were also the sites for R 1881. However, no progestin-binding component was observed in the nuclear extract of the benign prostatic hypertrophy, only R 1881-binding protein was detected in the present experiments. These results suggested that the progestin-binding protein in cytosols of the human benign prostatic hypertrophy is not a binder having the nature of the steroid hormone receptor. A part of the $R$ 1881-binding protein in cytosols might be the androgen receptor, but most of the $\mathrm{R} 1881$ binding is likely to be attributable to the progestin-binding component. Recently these two bindings of R 1881 were separated by use of triamcinolone acetonide as an inhibitor of progestin binding (Asselin et al., 1979; Zava et al. 1979, Hicks and Walsh, 1979). However, in our study the maximum binding sites in cytosols to R 1881 assayed in the presence of triamcinolone acetonide were well correlated with those to $R 1881$ estimated in the absence of triamcinolone acetonide (Nozumi et al., 1981). This seems to indicate that the supplementation of triamcinolone acetonide does not completely separate the binding of androgen from that of progestin.

Although androgenic, antiandrogenic and synandrogenic actions of progestin on males were observed, these actions are probably mediated by the androgen receptor, since there has been no evidence indicating the presence of progestin receptor in the prostate 
(Bullock et al., 1978). Further studies will be awaited to clarify the physiological and pathological roles of progestin-binding protein in the human prostate.

\section{Acknowledgements}

This work was supported in part by Grants-inAid for Cancer Research from the Ministry of Health and Welfare and from the Ministry of Education, Science and Culture, and for Scientific Research from the Ministry of Education, Science and Culture, Japan.

\section{References}

Asselin, J., F. Labrie, Y. Gourdeau, C. Bonne and J. P. Raynaud (1976). Binding of $\left[{ }^{3} \mathrm{H}\right]-$ methyltrienolone ( $R$ 1881) in rat prostate and human benign prostatic hypertrophy (BPH). Steroids 28 , 449-459.

Asselin, J., R. Mélançon, Y. Gourdeau, F. Labrie, C. Bonne and J. P. Raynaud (1979). Specific binding of $\left[{ }^{3} \mathrm{H}\right]$-methyltrienolone to both progestin and androgen binding components in human benign prostatic hypertrophy $(\mathrm{BPH}) . \quad J$. Steroid Biochem. 10, 483-486.

Blobel, G. and V. R. Potter (1966). Nuclei from rat liver: Isolation method that combines purity with high yield. Science 154, 1662-1665.

Bullock, L. P., W. Bardin and M. R. Sherman (1978). Androgenic, antiandrogenic and synandrogenic actions of progestins: Role of steric and allosteric interactions with androgen receptors. Endocrinology 103, 1768-1782.

Cowan, R. A., S. K. Cowan and J. K. Grant (1977). Binding of methyltrienolone ( $R$ 1881) to a progesterone receptor-like component of a human prostatic cytosol. J. Endocrinol. 74, 218-289.

Dubé, J. Y., P. Chapdelaine, R. R. Tremblay, C. Bonne and J. P. Raynaud (1976). Comparative binding specificity of methyltrienolone in human and rat prostate. Horm. Res. 7, 341-347.

Ekman, P., M. Snochowski, E. Dahlberg and J. Å. Gustafsson (1979). Steroid receptors in matastatic carcinoma of the human prostate. Eur. J. Cancer 15, 257-262.

Gornall, A. G., C. J. Bardawill and M. M. David (1949). Determination of serum proteins by means of the biuret reaction. J. Biol. Chem. 177, 751-766.

Gustafsson, J. А., P. Ekman, А. Pousette, M. Snochowski and B. Högberg (1979). Demonstration of a progestin receptors in human benign prostatic hyperplasia and prostatic carcinoma. Invest. Urol. 15, 361-366.

Hicks, L. L. and P. C. Walsh (1978). A microassay for the measurement of androgen receptors in human prostatic tissue. Steroids 33, 389-406.

Ichii, S. (1975). 5 5 -Dihydrotestosterone binding protein in rat ventral prostate: Purification, nuclear incorporation and subnuclear localization. Endocrinol. Japon. 22, 433-437.

Jänne, O., K. Kontula and R. Vihko (1976). Progestin receptors in human tissues: Concentrations and binding kinetics. J. Steroid Biochem. 7, 10611068.

Kodama, T. and J. Shimazaki (1979). Properties of androphilic proteins in cytosols of human benign prostatic hypertrophy. Endocrinol. Japan. 26, 449 458.

Kodama, T., S. Honda and J. Shimazaki (1977) Androphilic proteins in cytosols of human benign prostatic hypertrophy. Ibid. 24, 565-573.

Kodama, T., C. Hasebe and J. Shimazaki (1980). Binding to $\mathrm{R} 1881$ (methyltrienolone) of proteins from human benign prostatic hypertrophy. Ibid. 27, 229-237.

Koenders, A. J. M., J. Geurts-Moespot, L. V. A. M. Beex and T. J. Benraad (1979). Assay of progesterone receptor binding sites with 17,21-dimethyl19-norpregna-4, 9-diene-3, 20-dione and 16 $\alpha$ ethyl-21-hydroxy-19-nor-4-pregnene-3, 20-dione as the radioactive ligands. $J$. Endcrinol. 80, $15 \mathrm{p}$.

Kontula, K. (1975). Progesterone-binding protein in human myometrium. Binding site concentration in relation to endogenous progesterone and estradiol-17 $\beta$ levels. J. Steroid Biochem. 6, 15551561.

Menon, M., C. E. Tananis, L. L. Hicks, E. F. Hawkins, M. G. McLoughlin and P. C. Walsh(1978). Characterization of the binding of a potent synthetic androgen, methyltrienolone, to human tissues. J. Clin. Invest. 61, 150-162.

Menon, M., C. E. Tananis, M. G. McLoughlin and P. C. Walsh (1977). Androgen receptors in human prostatic tissue: A review. Cancer Treat. Rep. 61, 265-271.

Nozumi, K., R. Sato, H. Ito, M. Maruoka and J. Shimazaki (1981). Binding of dihydrotesterone, R 1881 and R 5020 in cytosols from normal, benign hypertrophic and cancerous human prostates. Urol. Int. 36, (2) in press.

Philibert, D., T. Ojasoo and J. P. Raynaud (1977). Properties of the cytoplasmic progestin-binding protein in the rabbit uterus. Endcrinology 101, 1850-1861.

Scatchard, G. (1949). The attractions of proteins for small molecules and ions. Ann. N. Y. Acad. Sci. 15, 660-672.

Shain, S. A. and R. W. Boesel (1978). Human prostate steroid hormone receptor quantitation. Current methodology and possible utility as a 
clinical discriminant in carcinoma. Invest. Urol. 16, 169-174.

Shain, S. A., R. W. Boesel, D. L. Lamm and H. M. Radwin (1978). Characterization of unoccupied (R) and occupied (RA) androgen binding components of the hyperplastic human prostate. Steroids 31, 541-556.

Tilley, W. D., D. D. Keightley and V. R. Marshall (1980). Oestrogen and progesterone receptors in benign prostatic hyperplasia in humans. J. Steroid
Biochem. 13, 395-399.

Tombs, M. P., T. Souter and N. F. Maclagen (1959). The spectrophotometric determination of protein at $210 \mathrm{~m} \mu$. Biochem. J. 73, 167-171.

Zava, D. T., B. Landrum, K. B. Horwitz and W. L. McGuire (1979). Androgen receptor assay with $\left[{ }^{3} \mathrm{H}\right]$ methyltrienolone ( $\left.\mathrm{R} 1881\right)$ in the presence of progesterone receptors. Endocrinology 104, 10071012. 